\title{
Are the Activities of the Internal Audit Function Associated with Audit Committee Quality Factors?
}

\author{
İrem Nuhoğlu* \\ Boğaziçi University
}

\author{
Audrey A. Gramling** \\ Colorado State University
}

\author{
David A. Wood*** \\ Brigham Young University
}

\begin{abstract}
This study examines the association between the characteristics of the audit committee and the characteristics of the internal auditing function in public companies in Turkey. The motivation for this study stems from the important impact that effective internal auditing has on corporate governance and the limited academic literature and regulatory guidelines that explore the relationship between internal audit work and audit committee characteristics in Turkish companies. We examine the association between the size and activities of an internal audit function and audit committee quality factors, including its membership characteristics and its relationship with the IAF. The results suggest that the independence of the audit committee and audit committee experience in financial executive levels are relative to the amount of time spent on risk management.
\end{abstract}

Keywords: corporate governance, financial control techniques, internal audit, audit committee, internal control, Turkey.

\section{İç Kontrol Teknikleri ile Denetim Komitesi Özellikleri arasında İlişki var mı?}

\section{Özet}

$\mathrm{Bu}$ araştırma şirketlerdeki finansal kontrol tekniklerinin özelliklerini ve etkinliğini araştırmaktadır. Çalışmada, Türkiye'de halka açık şirketlerde kurumsal yönetişim ilkelerinde benimsenmiş ve iç finansal kontrol tekniklerinin en önemli araçı olan iç denetim fonksiyonun ve iç denetim komitesinin niteliklerinin ilişkileri incelenmiştir. Bu çalışma finansal tabloların şeffaflığının ve doğruluğunun giderek önem kazandığı gerçeğinden ve tabloların paydaşların kararlarında etkinliğinden yola çıarak etkin finansal kontrolün sağlanabilmesi için gerekli unsurları araştırmayı hedeflemiştir. Araştırma, şirketlerin denetim komitesindeki bağımsız üye sayısı ve finans konularında ve yöneticilik tecrübesi olan üyelerin sayısı ile finansal kontrol tekniklerine ayrılan zaman arasında anlamlı ve

\footnotetext{
* İ́rem Nuhoğlu is a Professor in the Department of Management at Boğaziçi University, 34342, Bebek, Istanbul, Turkey. E-mail: nuhoğlun@boun.edu.tr

** Professor Audrey Gramling is Accounting Department Chair in the College of Business at Colorado State University, 1201 Campus Delivery, 80523, Fort Collins, Colorado, USA. E-mail: audrey,gramling@business.colostate.edu

*** David A. Wood is an Assistant Professor in the School of Accountancy at Brigham Young University, 84602, Provo, Utah, USA. E-mail: davidwood@byu.edu
} 
olumlu bir ilişki bulmuştur. Denetim komitesinin bağımsızlı̆̆ arttıkça ve finansal konularda ve yöneticilik tecrübesi olan üyelerin bulunduğu komitelere sahip olan örneklemdeki şirketlerde finansal kontrol tekniklerine daha çok zaman harcandığı görülmüsşür.

Anahtar kelimeler: kurumsal yonetim, finansal kontrol, iç denetim, denetim komitesi, iç kontrol, Türkiye.

$\mathrm{T}$ This study examines, for public companies in Turkey, the association between the size and activities of an internal audit function (IAF) and audit committee (AC) quality factors, including its membership characteristics and its relationship with the IAF. The motivation for this study stems from the growing importance in Turkish companies of the IAF and the limited academic literature that explores the relationship between internal audit work and AC characteristics.

Prior studies of non-Turkish companies have investigated various aspects of the relationship between the AC and the IAF (see Abbott et al., 2010; Zain et al., 2006; Carcello et al., 2005; Carcello et al., 2003; Chambers, 2005; Paape et al., 2003; Goodwin, 2003; Goodwin and Yeo, 2001; Raghunandan et al., 2001; Scarbrough et al., 1998; AlTwaijry et al., 2002). Although these studies make important contributions, Gramling et al. (2004) suggest that a greater understanding of the relationship between the AC and IAF is needed to achieve higher quality corporate governance. The purpose of this study is to increase the understanding of the relationship between the AC and the IAF by studying this relationship in an emerging economy where the internal audit profession is relatively new and corporate governance is still developing.

We examine the following AC membership characteristics: the number of members in the $\mathrm{AC}$, the number of independent $\mathrm{AC}$ members that have no connections with the firm, and the experience (i.e., financial, accounting, supervisory) of AC members. In terms of the relationship between the IAF and the AC, we examine the following relationships: the prevalence of communication between the $\mathrm{AC}$ and the IAF outside of regularly scheduled meetings, the degree of influence the $\mathrm{AC}$ has on determining the IAF budget, the insistence of the AC to have relevant and timely reporting from the IAF, the $A C$ 's request to the IAF to help with enterprise risk management (ERM), and the AC's request to the IAF to perform strategic audits (e.g., corporate governance audit). Our study investigates the association between these AC factors and certain characteristics of the IAF and its work, including the number of professional auditors in the IAF and the percentage of time spent on various assurance and consulting activities of the IAF.

Our results reveal that the percentage of time the IAF devotes to various types of assurance and consulting services is significantly and positively associated with the level of independence of the AC. Furthermore, the size of the IAF is postively and signficantly associated with the supervisory experience of the AC members and the influence that the $\mathrm{AC}$ has on the IAF budget. However, we find no evidence that the variables measuring the relationship between the AC and the IAF are signficantly associated with IAF actvities.

Next we discuss our motivation for this study, followed by a discussion of the methodology. Then, we present the results of the survey and conclude by discussing our study's contributions and limitations, and by providing suggestions for future research. 


\section{Background and Hypotheses}

\section{The AC and IAF in Turkey}

Although U.S. companies have been employing internal auditors since the mid19th century (Previts and Merino, 1998), the establishment of the Institute of Internal Auditors (IIA) in 1941 began the systematic development of the internal audit profession in the U.S. The purpose of the IIA is to be the internal audit profession's global voice, recognized authority, and principal educator of internal audit practices. In their definition of internal auditing, the IIA and Turkish Internal Audit Institute (TIDE) clearly state that the IAF provides both assurance and consulting services intended to add value to their organizations. ${ }^{[1]}$ This definition implies that the IAF should not only focus its efforts on assurance activities, but should also focus on consulting services in areas such as risk management, internal controls, and corporate governance (Chapman and Anderson, 2002).

Significant research on internal auditing in the US shows that the IAF improves corporate governance through a variety of different activities including (but not limited to): risk assessments (Sarens and De Beelde 2006; Asare et al. 2008), safeguarding of assets (Beasley et al. 2000; Coram et al. 2008), reducing earnings management and manipulation (Prawitt et al. 2009; Christ et al. 2014; Prawitt et al. 2012), improving external audit efficiency (Felix et al. 2001; Prawitt et al. 2011; Messier et al. 2011), improving internal control evaluation (Lin et al. 2011), and increased monitoring (COSO 2009). Although this research provides important evidence of the importance of internal auditing, relatively little is known about internal auditing in Turkey, an important developing economy.

Turkey has been restructuring its business environment for the last two decades in response to the country's transformation from a state-controlled economy to one that is a free market economy. The Corporate Governance Principles (CGP) issued by the CMB in 2003, (and amended in 2005 and 2012) focuses primarily on the importance of corporate governance within organizations, including guidance on the formation of the $\mathrm{AC}$ and its responsibilities. Public companies listed on the Istanbul Stock Exchange (ISE) are advised to follow the CGP guidelines and report the extent to which their organizations comply with the CGP, or to explain the reasons for any noncompliance. The duties of the $\mathrm{AC}$ are defined in Article 5 of the CGP. Of relevance to the current study, the CGP states that a duty of the AC is to "take all necessary measures to ensure that internal and external auditing are carried out adequately and transparently." Moreover, the new Turkish Commercial Code (TCC), effective in 2012, requires all companies, both those publicly listed and not, to form an AC to monitor the IAF (TCC, Article 366).

Despite these advances in Turkish legislation, internal auditing is still a developing profession in Turkey. Though their numbers are growing rapidly, internal auditing was

[1] The definition of internal auditing set forth by the IIA is the following: "Internal auditing is an independent, objective assurance and consulting activity designed to add value and improve an organization's operations. It helps an organization accomplish its objectives by bringing a systematic, disciplined approach to evaluate and improve the effectiveness of risk management, control, and governance processes" (IIA 2011). 
not seen as a serious profession in Turkey until the first Internal Audit Congress was held in 1977. Although the importance of the IAF has been identified in both the CGP and the Turkish Commercial Code, the IAF's role in organizations has not been defined in Turkish legislation as clearly as the responsibilities of the AC have been. The TIDE aims to expand the profession's influence in Turkey.

A comparative study of a developed and developing country (Gramling et al. 2013) provides evidence on IAF factors associated with these types of impact and whether these factors, and their influence on various other impacts, differ between a developed and an emerging economy (i.e. the USA and Turkey). Factors positively associated with financial reporting in the USA are assurance activities, control work, and competence; in Turkey, significant factors are governance work and competence. For governance, it is found that the factors positively associated with it in the USA include assurance activities, governance work, and competence; in Turkey, the significant factors are governance work and competence. In the USA, assurance activities are negatively associated with adding value, while consulting activities, risk work, and control work are positively associated with this measure. In Turkey, only risk work and control work are positively associated with adding value. The study finds significant differences between the two countries in terms of IAF characteristics. Specifically, it is found that there are significant differences in both competence and objectivity between internal auditors in the two countries. Turkey respondents perceive internal auditors to be more competent and more objective than do US respondents. The results of this study raise a number of questions that are considered in this paper about IAF and AC structure in Turkey.

There is little research on the relationship between the AC and the IAF in Turkey. The primary extant research focuses on describing the structure of the AC (Tuan and Sağlar, 2004), the effectiveness of audit committees on internal controls Y1lanc1, 2003; Çatıktaş and Yurtsever, 2007; Demirbaş, 2006), and the effectiveness of the IAF on supervision of the financial and operational activities of the company (Akış1k, 2005; Çatak, 2005; Köroğlu and Uçma, 2006; Memiş, 2007; Öksüz, 2005). This research emphasizes the critical importance of internal auditing; however, research has not yet examined the interactions between the AC and the IAF.

Goodwin (2003) suggests that future research should aim at providing more of a detailed understanding of how cooperation between the AC and the IAF can lead to stronger corporate governance. As a starting point for obtaining that understanding within a developing country, we provide evidence on how AC membership characteristics and its interactions with the IAF are associated with IAF size and activities.

\section{AC Characteristics and its Interactions with the IAF}

The CGP suggest that the $\mathrm{AC}$ is expected to enact the provisions necessary to increase the quality of both internal and external audit services. Academic research provides additional insights on these issues (Abbott and Parker, 2000; Carcello and Neal, 2000). In order to effectively enact such provisions, the AC must be made up of individuals that are knowledgeable, experienced, and competent in accounting, finance, and auditing. Abbot et al. (2004) find a significant negative association within the ACs that include 
at least one member with financial expertise and year-end restatements. Bédard et al. (2004) find that aggressive earnings management is negatively associated with the level of financial expertise of AC members in U.S. companies. Krishnan (2005) concludes that an $\mathrm{AC}$ that is independent and has members with financial expertise is significantly less likely to be associated with the incidence of internal control problems. Raghunandan and Rama (2007) find that there is a significantly positive association between the proportion of accounting experts on the $\mathrm{AC}$ and the number of meetings that lead to implementing effective internal controls. Sharma et al. (2009) posit that financial expertise is positively associated with meeting frequency, especially when the risk of financial misreporting is high. Naiker and Sharma (2009) suggest that the presence of former audit partners in the AC is associated with more effective monitoring of internal controls and financial reporting. Hoitash et al. (2009) conclude that the nature of the expertise and experience of AC members is associated with internal control quality. Gendron and Bedard (2006) have conducted an investigation through interviews in three large public companies in Canada to understand the effectiveness of AC. The study points out that the pressures to perform and be effective have a significant influence on the effectiveness of AC members.

In addition to these various $\mathrm{AC}$ characteristics that exert a positive influence on various corporate governance measures, we posit that such characteristics are also associated with the size of an IAF and the extent and type of activities performed by the IAF. For example, the AC's size and composition are major factors in determining how effectively it will monitor and supervise the activities of the IAF. Regulatory authorities and guidance such as the Public Oversight Board (POB) (1993) and the Sarbanes-Oxley Act (SOX) of 2002 posit that the more members on the AC that are independent and have financial expertise, the more effectively the $\mathrm{AC}$ is expected to fulfill its responsibilities.

Further, independence of the AC members is likely associated with IAF activities. For example, the results of several prior studies show that ACs composed of only independent members, with at least one having financial expertise, have more frequent and longer meetings with the IAF (Zain et al., 2006; Goodwin, 2003; Goodwin and Yeo, 2001; Raghunandan et al., 2001; Scarbrough et al., 1998), thereby potentially impacting IAF activities. Zain and Subramaniam (2007) in their study conducted in Malaysia report the existence of infrequent informal communications and limited private meetings between IAF manager and ACs. Bliss et al. (2007) posit that ACs provide an important check to moderate CEO dominance in firms where CEO duality is present in Malaysia. Sarens and De Beelde (2007), based upon Belgian case studies, point out that senior management expects the IAF and ACs to compensate for the loss of control they experience from increased organizational complexity.

The competence and expertise of AC members are also associated with IAF activities. For example, Naiker and Sharma (2009) suggest that having AC members with audit firm experience is the most effective way to reduce internal control problems in companies. We posit that the accounting, financial, and supervisory experience of AC members is associated with IAF size and activities. 
The AC typically has varied interactions with the IAF that may be associated with IAF size and activities. For example, Carcello et al. (2005) state that 59 percent of the chief internal auditors surveyed in the United States agreed that the AC reviews the IAF's annual budget. The degree of influence that the AC has on determining the IAF budget implies the degree of involvement that the $\mathrm{AC}$ has on the size and activities of the IAF. The insistence of the AC to have relevant and timely reporting of IAF shows the IAF's intention and the seriousness of its monitoring. One of the major responsibilities of the $\mathrm{AC}$ is to ensure that the organization's management has designed and implemented an effective IAF. The AC must review the IAF's work program and reports to ensure that the scope of the IAF's activities is adequate. The AC's role in reviewing the IAF's work increases the communication between the parties. The AC's request to the IAF to help with enterprise risk management (ERM) and its request to the IAF to perform strategic audits could be considered a request that the IAF perform consulting services.

The prevalence of communication between the $\mathrm{AC}$ and the IAF outside of regularly scheduled meetings relates to the involvement of the AC in the IAF's activities. Regulatory authorities, such as the POB, SEC, and the Blue Ribbon Commission emphasize that frequent meetings between the $\mathrm{AC}$ and IAF allow for more effective communication with the IAF and better monitoring of internal controls. McMullen and Raghunandan (1996) find that frequent meetings between the AC and the IAF reduce the likelihood of financial reporting problems, possibly because of the AC's increased involvement in IAF activities. Moreover, frequent ad hoc meetings between these two entities outside of those that are scheduled reduce the likelihood of fraud (Beasley et al.,1999), suspicious auditor switches (Archambeault and DeZoort, 2001), and restatements (Abbott et al, 2004). These positive effects of the relationship between the AC and IAF are likely to be the result of the AC having an influence on IAF size and activities.

\section{IAF Size and Activities}

Our focus herein is on whether AC characteristics and its relationship with the IAF are associated with IAF size and activities in Turkish public companies. For example, for U.S. companies, Abbot et al. (2010) find that there is a strong, positive association between AC oversight of the IAF and the amount of the IAF's budget that is allocated to work involving internal controls.

Our study explores the relationship between $\mathrm{AC}$ membership characteristics (i.e., the number of $\mathrm{AC}$ members, the number of independent $\mathrm{AC}$ members, the type of expertise of $\mathrm{AC}$ members) and the interactions between the $\mathrm{AC}$ and the IAF (i.e., the attempt of AC members to know the IAF outside of regularly scheduled meetings, the degree of influence that the $\mathrm{AC}$ has on determining the IAF budget, the insistence of the $\mathrm{AC}$ on relevant and timely reporting of IAF, the call of the AC on IAF to help with enterprise risk management (ERM), and the call of the AC on IAF to conduct a strategic audit of the number of professional auditors in the IAF, and on the proportion of time that the IAF spends on assurance and consulting activities (see Table 1). 
Table 1

Posited Relationships between AC Characteristics and its IAF Interactions and IAF Size and Activities

\begin{tabular}{|c|c|c|}
\hline AC Characteristics and its Interactions with the IAF & \multicolumn{2}{|c|}{ IAF Size and Activities } \\
\hline Characteristic: The number of AC members & \multirow{9}{*}{ 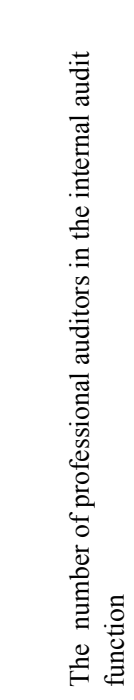 } & \multirow{9}{*}{ 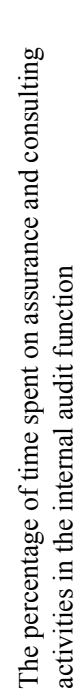 } \\
\hline Characteristic: The number of independent AC members & & \\
\hline Characteristic: The expertise of $\mathrm{AC}$ members & & \\
\hline Interaction: The prevalence of communication between the $\mathrm{AC}$ and the & & \\
\hline IAF outside of regularly scheduled meetings & & \\
\hline $\begin{array}{l}\text { Interaction: The degree of influence that the AC has in determining the } \\
\text { IAF budget }\end{array}$ & & \\
\hline $\begin{array}{l}\text { Interaction: The insistence of AC with relevant and timely reporting of } \\
\text { IAF }\end{array}$ & & \\
\hline $\begin{array}{l}\text { Interaction: The AC's request to the IAF to help with enterprise risk } \\
\text { management (ERM) }\end{array}$ & & \\
\hline $\begin{array}{l}\text { Interaction: The AC's request to the IAF to perform strategic audit (e.g., } \\
\text { corporate governance audit) }\end{array}$ & & \\
\hline
\end{tabular}

In summary, we posit that the three $\mathrm{AC}$ characteristics and the five $\mathrm{AC}$ interactions with the IAF will have a positive association with the number of professional auditors in the IAF and on the proportion of time spent on assurance and consulting activities of the IAF.

\section{Methodology}

We conducted a survey of internal auditors in Turkish companies. A survey was provided to representatives from all 304 companies listed on the Istanbul Stock Exchange (ISE) because of the expectation that an IAF exists in these organizations. We received usable responses from 71 of the companies (23.2\% of the population). The survey was conducted by a professional company, and responses were collected through face-toface interviews (54 of the usable responses) and through an internet survey (17 of the usable responses). As indicated in Table 2, our respondents included both internal audit and non-internal audit professionals. Internal audit respondents primarily included chief audit executives and IAF managers/directors. The non-IAF respondents represented AC members, chief executive officers, and chief financial officers. 
Table 2

Descriptive Statistics of Survey Respondents

\begin{tabular}{l|c|c}
\hline Position & Respondents & Percent of Total \\
\hline Chief Audit Executive & 2 & 2.8 \\
\hline IAF Manager/Director & 32 & 45.1 \\
\hline Other Audit Position & 5 & 7.8 \\
\hline Non-internal audit respondents & 32 & 45.1 \\
\hline TOTAL & $\mathbf{7 1}$ & $\mathbf{1 0 0}$ \\
\hline
\end{tabular}

The respondents were asked to classify their companies in terms of manufacturing, service, or financial industries. For the purposes of this study, the manufacting industry includes production of food and dairy products; textile products; forestry, paper, and printing products; chemical and petroleum products; mining; metal products; and machinery and equipment production. The service industry includes trading and merchandising companies, electrical services, transportation, tourism, communication, and sports companies. Banks, insurance, leasing, investment, and real estate companies are considered part of the financial industry. As reported in Table 3, the majority of respondents (43.7\%) work in the financial industry.

Table 3

Descriptive Statistics of Companies of Survey Respondents

\begin{tabular}{l|c|c}
\hline Industry & Respondents & Percent of Total \\
\hline Manufacturing & 27 & 38.0 \\
\hline Services & 11 & 15.5 \\
\hline Financial & 31 & 43.7 \\
\hline Other & 2 & 2.8 \\
\hline TOTAL & $\mathbf{7 1}$ & $\mathbf{1 0 0}$ \\
\hline
\end{tabular}

The respondents were asked to indicate the range of total assets and net income for their companies for 2010; the responses, reported in the Turkish Lira (TL), can be seen in Table 4 and Table 5, respectively. 
Table 4

Descriptive Statistics of Companies of Survey Respondents: Total Assets

\begin{tabular}{l|c|c}
\hline Total Assets (Million TL) & Respondents & Percent of Total \\
\hline $0-9$ & 2 & 2.8 \\
\hline $50-99$ & 5 & 7.0 \\
\hline $100-249$ & 6 & 8.5 \\
\hline $250-499$ & 4 & 5.6 \\
\hline $500-999$ & 9 & 8,5 \\
\hline $1,000-1,999$ & 14 & 12.7 \\
\hline $2,000-9,999$ & 2 & 2.8 \\
\hline $10,000-49,999$ & 22 & 31.0 \\
\hline 50,000 and more & 1 & 1.4 \\
\hline Other (no response) & $\mathbf{7 1}$ & $\mathbf{1 0 0}$ \\
\hline TOTAL & & \\
\hline
\end{tabular}

Table 5

Descriptive Statistics of Companies of Survey Respondents' Net Income

\begin{tabular}{l|c|c}
\hline Net Profit (Million TL) & Respondents & Percent of Total \\
\hline 750 and more & 8 & 11.3 \\
\hline $250-749$ & 8 & 11.3 \\
\hline $100-249$ & 10 & 14.1 \\
\hline $50-99$ & 22 & 8.5 \\
\hline $1-49$ & 1 & 31.0 \\
\hline $0-0.9$ & 2 & 1.4 \\
\hline $0-(0.9)$ & 7 & 2.8 \\
\hline$(49)-(1)$ & 1 & 9.9 \\
\hline (249) - (100) & 2 & 1.41 \\
\hline (500) - (250) & 1 & 2.8 \\
\hline Greater than (500) & 3 & 1.4 \\
\hline Other (no response) & $\mathbf{7 1}$ & 4.2 \\
\hline TOTAL & & $\mathbf{1 0 0}$ \\
\hline
\end{tabular}


The variables used in this study come from a subset of questions from our survey that explore various issues related to the relationship between the AC and the IAF. We analyze our research issues, using the following model:

$\mathrm{Y} i=\alpha+\beta i \mathrm{X} i+\varepsilon$

Where dependent variables $(\mathrm{Y} i)$ are:

$\mathrm{Y}_{1}=$ The number of professional auditors in the IAF,

$\mathrm{Y}_{2}=$ The percentage of time the IAF spends on assurance $\left(\mathrm{Y}_{2 \mathrm{a}}\right)$ or consulting

$\left(\mathrm{Y}_{2 \mathrm{~b}}\right)$ services.

Where independent variables $(\mathrm{X} i)$ are,

$\mathrm{X}_{1}=$ The number of AC members

$\mathrm{X}_{2}=$ The percentage of independent AC members

$\mathrm{X}_{3}=$ The percentage of $\mathrm{AC}$ members that have accounting (a), financial (b),

or supervisory experience (c)

$\mathrm{X}_{4}=$ The prevalence of communication between the AC and the IAF outside of regularly scheduled meetings

$\mathrm{X}_{5}=$ The degree of influence that the AC has in determining the IAF budget

$\mathrm{X}_{6}=$ The insistence of $\mathrm{AC}$ to have relevant and timely reporting from the IAF

$\mathrm{X}_{7}=$ The AC's request to the IAF to help with enterprise risk management (ERM)

$\mathrm{X}_{8}=$ The AC's request to the IAF to perform strategic audits

We expect to observe a positive coefficient for each independent variable in the regression.

\section{Dependent Variables}

To examine the percentage of time spent on various activities, the participants were asked to state the percentage of time that their organization's IAF devoted to assurance and consulting for twelve different activities, including financial auditing, operational/efficiency auditing, information technology (IT) auditing, work-related CGP, external auditing direct assistance, statutory audits such as insurance regulations and public utility regulations, training of company employees, training of AC and board members, fraud investigations, compliance work other than CGP, risk assessment, and other services. The dependent variable is iterated for the above listed twelve different auditing activities both for assurance and for consulting. Thus, we conduct twenty-five regression models to aid in our understanding of the association between $\mathrm{AC}$ factors and the size and activities of the IAF.

\section{Independent Variables}

Data on the number of AC members $\left(\mathrm{X}_{1}\right)$ and the percentage of independent $\mathrm{AC}$ members $\left(\mathrm{X}_{2}\right)$ is obtained from the survey questions. The experience of the $\mathrm{AC}$ members $\left(\mathrm{X}_{3}\right)$ is obtained from a question about the number of $\mathrm{AC}$ members that have professional experience in accounting $\left(\mathrm{X}_{3 \mathrm{a}}\right)$, finance $\left(\mathrm{X}_{3 \mathrm{~b}}\right)$, and supervisiory roles $\left(\mathrm{X}_{3 \mathrm{c}}\right)$. These experience categories are not mutually exclusive, meaning that an AC member may have experience in more than one category. Having accounting experience is defined 
as current or previous work as a CPA, CFO, vice president of finance, financial coordinator, or any other major accounting position. Having financial experience is defined as current or previous work as an investment banker, financial analyst, or any other financial management role. Supervisiory experience is defined as current or previous work as a CEO or company president.

We used a 7-point likert scale to measure the variables representing the interactions between the AC and the IAF, with higher numbers indicating more agreement with the statement. The following survey statements are used to measure these independent variables:

- At our organization, the AC attempts to get to know the IAF outside of regularly scheduled meetings $\left(\mathrm{X}_{4}\right)$,

- At our organization, the AC determines if the internal audit budget is sufficient $\left(\mathrm{X}_{5}\right)$,

- At our organization, the AC insists on the prioritization of audit issues, along with relevant and timely reporting $\left(\mathrm{X}_{6}\right)$,

- At our organization, the AC calls on internal audit to help with $\operatorname{ERM}\left(\mathrm{X}_{7}\right)$,

- At our organization, the AC calls on internal audit to perform strategic audits such as corporate governance audits $\left(\mathrm{X}_{8}\right)$.

\section{Results and Concluding Remarks}

The results of the regression analysis are presented in the Appendix. We discuss the results for each dependent variable separately, and summarized in Table 6. The insistence of $\mathrm{AC}$ to have relevant and timely reporting of IAF $\left(\mathrm{X}_{6}\right)$ and the AC's request to the IAF to help with enterprise risk management $\left(\mathrm{X}_{7}\right)$ are removed from the analysis due to collinearity.

\section{Results - The Number of Professional Auditors in the IAF ( $\left.\mathbf{Y}_{1}\right)$}

There is a positive and significant relationship between the number of professional auditors in the IAF and the percentage of AC members that have supervisory experience $\left(\mathrm{X}_{3 \mathrm{c}}\right)(\mathrm{p}$-value $<0.05)$, and the degree of influence that the $\mathrm{AC}$ has on determining the IAF budget $\left(\mathrm{X}_{5}\right)$ (p-value $\left.<0.10\right)$. As the number of AC members with supervisory experience increases, the number of professional auditors in the IAF increases. As the influence of the $\mathrm{AC}$ on the IAF budget increases, the number of professional auditors in the IAF increases.

Results - The Percentage of Time Spent on Assurance and Consulting Services ( $\left.\mathbf{Y}_{2}\right)$

As summarized in Table 6, there is a positive and significant relationship between the percentage of time spent on assurance and consulting services in the IAF and the percentage of independent AC members $\left(\mathrm{X}_{2}\right)(\mathrm{p}$-value $<0.05)$. The percentage of time spent in internal audit activities is more when there are more independent AC members in the commitee. Independency may promote the objectivity and the importance of internal control. These results provide an interesting insight as to the importance of the $\mathrm{AC}$ independence and IAF activities. 
Table 6

Summary of Signficant Results for the Association by AC Characteristics and IAF Activities ( $\left.\mathrm{Y}_{2}\right)$

\begin{tabular}{|c|c|}
\hline $\begin{array}{l}\text { AC Characteristics Significant } \\
\text { Independent Variables }(\mathbf{X i})\end{array}$ & $\begin{array}{l}\text { Significant Percentage of Time Spent on Assurance and/or Consulting Activities in } \\
\text { Internal Department } \quad(p-v a l u e s<0.05)\end{array}$ \\
\hline \multirow{2}{*}{$\begin{array}{l}\text { The percentage of independent } \\
\text { AC members }\left(\mathrm{X}_{2}\right)\end{array}$} & $\begin{array}{l}\text { Assurance Activities } \\
\text { Financial Auditing } \\
\text { Operational/efficiency Auditing } \\
\text { IT Auditing } \\
\text { Work Related CGP } \\
\text { External Auditing Direct Assistance } \\
\text { Statutory Audits like Insurance Regulations and Public Utility Regulations } \\
\text { Training of Company Employees including Management } \\
\text { Training of AC and Board Members } \\
\text { Fraud Investigations } \\
\text { Compliance Work other than CGP } \\
\text { Risk Assessment } \\
\text { Other Services }\end{array}$ \\
\hline & $\begin{array}{l}\text { Consulting Activities } \\
\text { Financial Auditing } \\
\text { Operational/efficiency Auditing } \\
\text { IT Auditing } \\
\text { Work Related CGP } \\
\text { External Auditing Direct Assistance } \\
\text { Statutory Audits like Insurance Regulations and Public Utility Regulations } \\
\text { Training of Company Employees including Management } \\
\text { Training of AC and Board Members } \\
\text { Fraud Investigations } \\
\text { Compliance Work other than CGP } \\
\text { Risk Assessment } \\
\text { Other Services }\end{array}$ \\
\hline $\begin{array}{l}\text { The percentage of } \mathrm{AC} \text { members } \\
\text { that have financial experience } \\
\left(\mathrm{X}_{3 \mathrm{~b}}\right)\end{array}$ & $\begin{array}{l}\text { Assurance Activities } \\
\text { External Auditing Direct Assistance }\end{array}$ \\
\hline $\begin{array}{l}\text { The percentage of } \mathrm{AC} \\
\text { members that have supervisory } \\
\text { experience }\left(\mathrm{X}_{3 \mathrm{c}}\right)\end{array}$ & $\begin{array}{l}\text { Consulting Activities } \\
\text { Operational/efficiency Auditing }\end{array}$ \\
\hline $\begin{array}{l}\text { AC Characteristics Significant } \\
\text { Independent Variables }\left(\mathrm{X}_{\mathrm{i}}\right)\end{array}$ & $\begin{array}{l}\text { Significant Percentage of Time Spent on Assurance and/or Consulting Activities in } \\
\text { Internal Department } \quad(p \text {-values }<0.10)\end{array}$ \\
\hline \multirow{2}{*}{$\begin{array}{l}\text { The percentage of } \mathrm{AC} \text { members } \\
\text { that have financial experience } \\
\left(\mathrm{X}_{3 \mathrm{~b}}\right)\end{array}$} & $\begin{array}{l}\text { Assurance Activities } \\
\text { Financial Auditing } \\
\text { Statutory Audits like Insurance Regulations and Public Utility Regulations } \\
\text { Training of Company Employees including Management } \\
\text { Training of AC and Board Members }\end{array}$ \\
\hline & $\begin{array}{l}\text { Consulting Activities } \\
\text { Financial Auditing } \\
\text { Work Related CGP } \\
\text { External Auditing Direct Assistance } \\
\text { Statutory Audits like Insurance Regulations and Public Utility Regulations }\end{array}$ \\
\hline \multirow{2}{*}{$\begin{array}{l}\text { The percentage of } \mathrm{AC} \\
\text { members that have supervisory } \\
\text { experience }\left(\mathrm{X}_{3 \mathrm{c}}\right)\end{array}$} & $\begin{array}{l}\text { Assurance Activities } \\
\text { Financial Auditing } \\
\text { Operational/efficiency Auditing } \\
\text { Training of AC and Board Members }\end{array}$ \\
\hline & $\begin{array}{l}\text { Consulting Activities } \\
\text { Work Related CGP }\end{array}$ \\
\hline
\end{tabular}


There also is a positive and significant ( $\mathrm{p}$-value $<0.05$ ) relationship between the percentage of time spent on assurance and consulting services in the IAF and the percentage of independent $\mathrm{AC}$ members that have financial experience $\left(\mathrm{X}_{3 \mathrm{~b}}\right)$. This result highlights the importance in financial experience of $\mathrm{AC}$ members if the company is looking for assistance in external auditing to attain and maintain an effective communication with the auditing company. There is also a positive and significant (p-value $<$ $0.10)$ relationship between the percentage of time spent on assurance and consulting services in the IAF and the percentage of independent $\mathrm{AC}$ members that have financial experience $\left(\mathrm{X}_{3 \mathrm{~b}}\right)$ with respect to assurance activities of financial auditing, statutory audits, and training, and to consulting activities of financial auditing, work related CGP, external auditing, and statutory audits.

There is a positive and significant ( $\mathrm{p}$-value $<0.05$ ) relationship between the percentage of time spent on assurance and consulting services in the IAF and the percentage of independent $\mathrm{AC}$ members that have supervisory experience $\left(\mathrm{X}_{3 \mathrm{c}}\right)$ with respect to consulting activities of operational auditing. The percentage of time spent in operational auditing is more when there are more $\mathrm{AC}$ members with supervisory experience in the committee. A positive and significant $(\mathrm{p}$-value $<0.10)$ relationship also exists between the percentage of time spent on assurance and consulting services in the IAF and the percentage of independent $\mathrm{AC}$ members that have supervisory experience $\left(\mathrm{X}_{3 \mathrm{c}}\right)$ with respect to assurance activities of financial auditing, operational auditing, and training and to consulting activities of work related CGP.

\section{Concluding Remarks}

In conclusion, the survey suggests that there is positive and significant relationship between the percentage of time spent on IAF and the percentage of independent AC members and members with financial and supervisory experience.

Our results provide interesting first insights into the analysis of the relationship between AC and IAF in Turkish public companies. The results suggest that some AC factors are significantly associated with IAF size and IAF activites. Recall that this study is a starting point for understanding how factors related to the AC and the IAF can lead to stronger corporate governance. Further steps include examining approaches for improving the relationship between the IAF and the AC and for identifying the corporate governance benefits that might result from enhanced AC and IAF relationships.

Overall, we believe the results are thought-provoking and useful as a beginning point for advancing our understanding of the relation between AC and IAF. We encourage researchers to continue this examination in Turkey. 


\section{References}

Abbott, L.J. and Parker, S. (2000). “Audit Committee Characteristics and Auditor Choice," Auditing: Journal of Practice and Theory, 1(2): 47-66.

Abbott, L.J., Parker, S., and Peters, G.F. (2004). “Audit Committees' Characteristics and Restatements," Auditing: Journal of Practice and Theory, 23(1): 69-87.

, (2010., "Serving Two Masters: The Association between Audit Committee Internal Audit Oversight and Internal Audit Activities," Accounting Horizons, 2(1): 1-24.

Akışık, O. (2005), "İç Kontrol Sistemi ve Bağımsız Denetim Içindeki Yeri," Muhasebe ve Denetime Bakış, 4(14).

Al-Twaijry, A., Brierley, J.A., and Gwilliam, D. (2002). "An Examination of Audit Committees in the Saudi Arabian Corporate Sector," Corporate Governance: An International Review, 10: 288-297.

Archambeault, D. and Dezoort, F.D. (2001). "Auditor Opinion Shopping and the Audit Committee: An Analysis of Suspicious Auditor Switches," International Journal of Auditing, 5(1): 33-52.

Asare, S.K., Davidson, R.A., and Gramling, A.A. (2008). "Internal Auditors' Evaluation of Fraud Factors in Planning an Audit: The Importance of Audit Committee Quality and Management Incentives," International Journal of Auditing, 12(3): 181-203.

Beasley, M.S., Carcello, J.V., and Hermanson, D.R. (1999). "Fraudulent Financial Reporting: 19871997, An Analysis of US Public Companies," The Auditor's Report, 22(3): 15-17.

Beasley, M.S., Carcello, J.V., Hermanson, D.R., and Lapides, P.D. (2000). "Fraudulent Financial Reporting: Consideration of Industry Traits and Corporate Governance Mechanisms," Accounting Horizons, 14: 441-454.

Bédard, J., Chtourou, S.M., and Courteau, L. (2004). "The Effect of Audit Committee Expertise, Independence, and Activity on Aggressive Earnings Management," Auditing: A Journal of Practice and Theory, 23(2): 13-35.

Bliss, M.A., Muniandy, B., and Majid, A. (2007). "CEO Duality, Audit Committee Effectiveness and Audit Risks: A Study of the Malaysian Market," Managerial Auditing Journal, 22(7): 716-728.

Carcello, J.V., Hermanson, D., and Raghunandan, K. (2005). "Factors Associated with US Public Companies' Investment in Internal Auditing," Accounting Horizons, 19(2): 69-84.

Carcello, J.V and Neal, T.L. (2000). "Audit Committee Characteristics and Auditor Reporting," The Accounting Review, 75(4): 453-467.

------, (2003). "Audit Committee Independence and Disclosure: Choice for Financially Distressed Firms," Corporate Governance: An International Review, 11: 289-299.

Chambers, A. (2005). "Audit Committees: Practice, Rules, and Enforcement in the UK and China," Corporate Governance: An International Review, 13(1): 92-100.

Chapman, C. and Anderson, U. (2002). "Implementing the Professional Practices Framework," Altamonte Springs, FL, The Institute of Internal Auditors Foundation.

Christ, M.H., Sharp, N.Y., Masli, A., and Wood, D.A. (2014). "Using the Internal Audit Function as a Management Training Ground: Is the Monitoring Effectiveness of Internal Auditors Compromised?" Working Paper.

Committee of Sponsoring Organizations of the Treadway Commission (COSO) (2009). COSO Guidance on Monitoring Internal Control Systems, Durham, NC: COSO.

Coram, P., Ferguson, C., and Moroney, R. (2008). "Internal Audit, Alternative Internal Audit Structures and the Level of Misappropriation of Assets Fraud," Accounting and Finance, 48: 543-559. 
Çatak, T.S. (2005). "İ̧̧letmelerde İç Kontrol Sistemini Oluşturan Unsurlardan Kontrol Çevresinin İncelenmesi," Mevzuat Dergisi, 8(91).

Çatikkaş, Ö. and Yurtsever, G. (2007). "Türkiye Uygulamaları Açısından Denetim Komiteleri üzerine bir Değerlendirme," Mali Çözüm Dergisi, 81.

Demirbaş, M. (2006). “Türkiye'de Denetim Komitesi Üyelerinin Bağımsızlığının ve Etkinliğinin Halka Açık Anonim Şirketlerde Tesbit Edilmesi,” MÖDAV Muhasebe Bilim Dünyası Dergisi, 8(3): 105-132.

Felix, W.L., Gramling, A.A., and Maletta, M.J. (2001). "The Contribution of Internal Audit as a Determinant of External Audit Fees and Factors Influencing this Contribution," Journal of Accounting Research 39(3): 513.

Gendron, Y. and Bedard, J. (2006). "On the Constitution of Audit Committee Effectiveness," Accounting, Organizations and Society, 31(3): 211-239.

Goodwin, J. (2003). "The Relationship between the Audit Committee and the Internal Audit Function: Evidence from Australia and New Zealand," International Journal of Auditing, 7(3): 263-278.

Goodwin, J. and Yeo, T.Y. (2001). "Two Factors Affecting Internal Audit Independence and Objectivity: Evidence from Singapore," International Journal of Auditing, 5(2): 107-125.

Gramling, A., Wood, D., and Nuhoğlu, I. (2013). "A Descriptive Study of Factors Associated with the Internal Audit Function Policies Having an Impact: Comparisons between Organizations in a Developed and an Emerging Economy," Turkish Studies, 14(3): 1-26.

Gramling, A., Maletta, M.J., Schneider, A., and Church, B.K. (2004). "The Role of the Internal Audit Function in Corporate Governance: A Synthesis of the Extant Internal Auditing Literature and Directions for Future Research," Journal of Accounting Literature, 23: 194-244.

Hoitash, U., Hoitash, R., and Bedard, J. (2009). "Corporate Governance and Internal Control over Financial Reporting: A Comparison of Regulatory Regimes,” The Accounting Review, 84(3): 839-867.

Institute of Internal Auditors (IIA) (1996). Standards for the Professional Practice of Internal Auditing. Altamonte Springs, FL, The Institute of Internal Auditors Foundation.

------, (2002a). The IIA's Recommendations to the Conference Committee on H.R. 3703. Altamonte Springs, FL, The Institute of Internal Auditors Foundation.

-----, (2002b). Recommendations for Improving Corporate Governance. Altamonte Springs, FL, The Institute of Internal Auditors Foundation.

-----, (2003b). The IIA's Commentary Regarding PCAOB Rulemaking Docket No. 008. Altamonte Springs, FL, The Institute of Internal Auditors Foundation.

------, (2011). The Definition of Internal Auditing. The Institute of Internal Auditors Foundation.

Köroğlu, Ç. and Uçma, T. (2006). "İşletmelerdeki İç Kontrol Sisteminin Etkinliği ve Diş Denetimdeki Önemi," Mevzuat Dergisi, 8(103).

Krishnan, J. (2005). "Audit Quality and Internal Control: An Empirical Analysis," The Accounting Review, 80(2): 649-675.

Lin, S., Pizzini, M., Vargus, M., and Bardhan, I.R. (2011). "The Role of the Internal Audit Function in the Disclosure of Material Weaknesses," The Accounting Review, 86(1): 287-323

McMullen, D.A. and Raghunandan, K. (1996). “Enhancing Audit Committee Effectiveness,”,Journal of Accountancy, 182: 79-81.

Memiş, M.Ü. (2007). “Türkiye'deki İç Denetim Profilinin Belirlenmesine ilişkin bir Araştırma," Çukurova Üniversitesi Sosyal Bilimler Estitüsü Dergisi, 16(1): 461-478. 
Messier, W.F., Reynolds, J.K., Simon,C.A., and Wood, D.A. (2011). The Effect of Using the Internal Audit Function as a Management Training Ground on the External Auditor's Reliance Decision," The Accounting Review, 86(6): 2131-2154.

Naiker, V. and Sharma, D.S. (2009). "Former Audit Partners on the Audit Committee and Internal Control Deficiencies," The Accounting Review, 84(2): 559-587.

Öksüz, F. (2005). “İç Denetim Departman Yönetiminde Etkinlik ve Verimlilik,” İç Denetim Dergisi, 12.

Paape, L., Scheffe, J., and Snoep, P. (2003). "The Relationship between the Internal Audit Function and Corporate Governance in the EU - A Survey," International Journal of Auditing, 7(3): 247-262.

Prawitt, D F., Smith,J.L., and Wood, D.A. (2009). "Internal Audit Characteristics and Earnings Management," The Accounting Review, 84(4): 1255-1280.

Prawitt, D.F., Sharp, N.Y., and Wood. D.A. (2011). "Reconciling Archival and Experimental Research: Does Internal Audit Contribution Affect the External Audit Fee?" Behavioral Research in Accounting 23(2): 187-206.

-----, (2012). "Internal Audit Outsourcing and the Risk of Misleading or Fraudulent Financial Reporting: Did Sarbanes-Oxley Get It Wrong?” Contemporary Accounting Research, 29(4): 1109-1136.

Previts, G.J., and Merino, B.D. (1998). A History of Accountancy in the United States: The Cultural Significance of Accounting. Columbus, OH: The Ohio State University Press.

Raghunandan, K., William, J R., and Rama, D.V. (2001). “Audit Committee Composition, Gray Directors and Interaction with Internal Auditing," Accounting Horizons, 15(2): 105-118.

Raghunandan, K. and Rama, D.V. (2007). "Determinants of Audit Committee Diligence," Accounting Horizons," 2(3): 265-280.

Scarbrough, D.P., Rama, D.V., and Raghunandan, K. (1998). "Audit Committee Composition and Interaction with Internal Auditing: Canadian Evidence," Accounting Horizons, 12(1): 51-62.

Sarens, G., and Beelde, I.De. (2006). "Internal Auditors' Perception about their Role in Risk Management," Managerial Auditing Journal, 21(1): 63-80.

. (2006). "The Relationship between Internal Audit and Senior Management: A Qualitative Analysis of Expectations and Perceptions," International Journal of Auditing, 10(3): 219-241.

Sharma, V.D., Naiker, V., and Lee, B. (2009). "Determinants of Audit Committee Meeting Frequency: Evidence from a Voluntary Governance System," Accounting Horizons, 23(3): 245-263.

Tuan, A.K. and Sağlar, J. (2004). "İç Denetçinin Örgüt İçindeki Yerinin Denetim Faaliyetleri Açısından Önemi," Muhasebe ve Denetime Bakış, 4(11).

Yılancı, M. (2003). "Denetim Komitesinin İç Etkinliğini Sağlamadaki ve Hileleri Önlemedeki Rolü," Muhasebe ve Denetime Bakış, 3(8).

Zain, M.M., Subramaniam, N., and Stewart, J. (2006). "Internal Auditors' Assessment of their Contribution to Financial Statement Audits: The Relation with Audit Committee and Internal Audit Function Characteristics," International Journal of Auditing, 10(1): 1-18.

Zain, M.M. and Subramaniam, N. (2007). "Internal Auditor Perceptions on Audit Committee Interactions: A Qualitative Study in Malaysian Public Corporations," Corporate Governance, an International Review, 15(5): 894-908. 


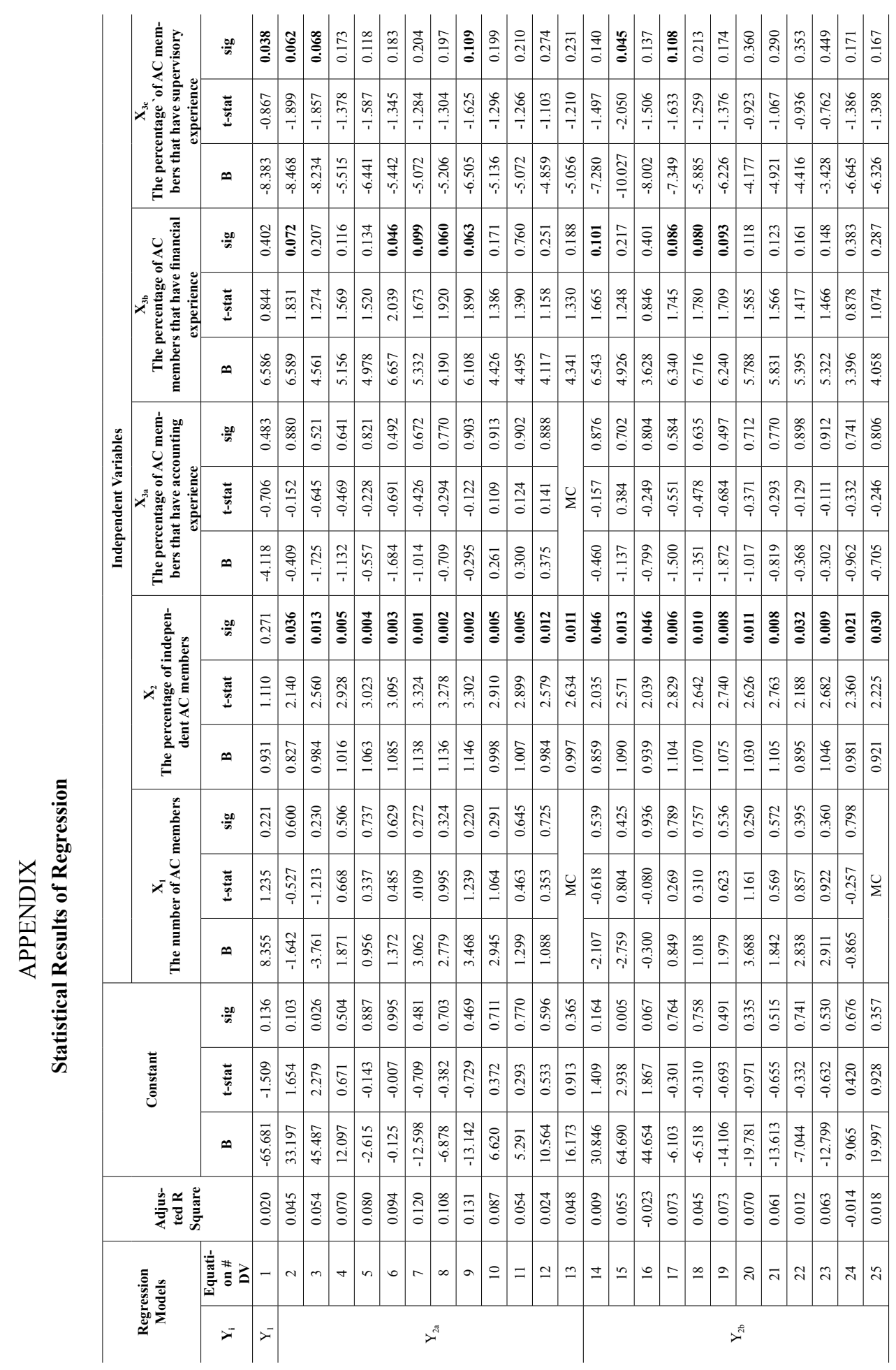




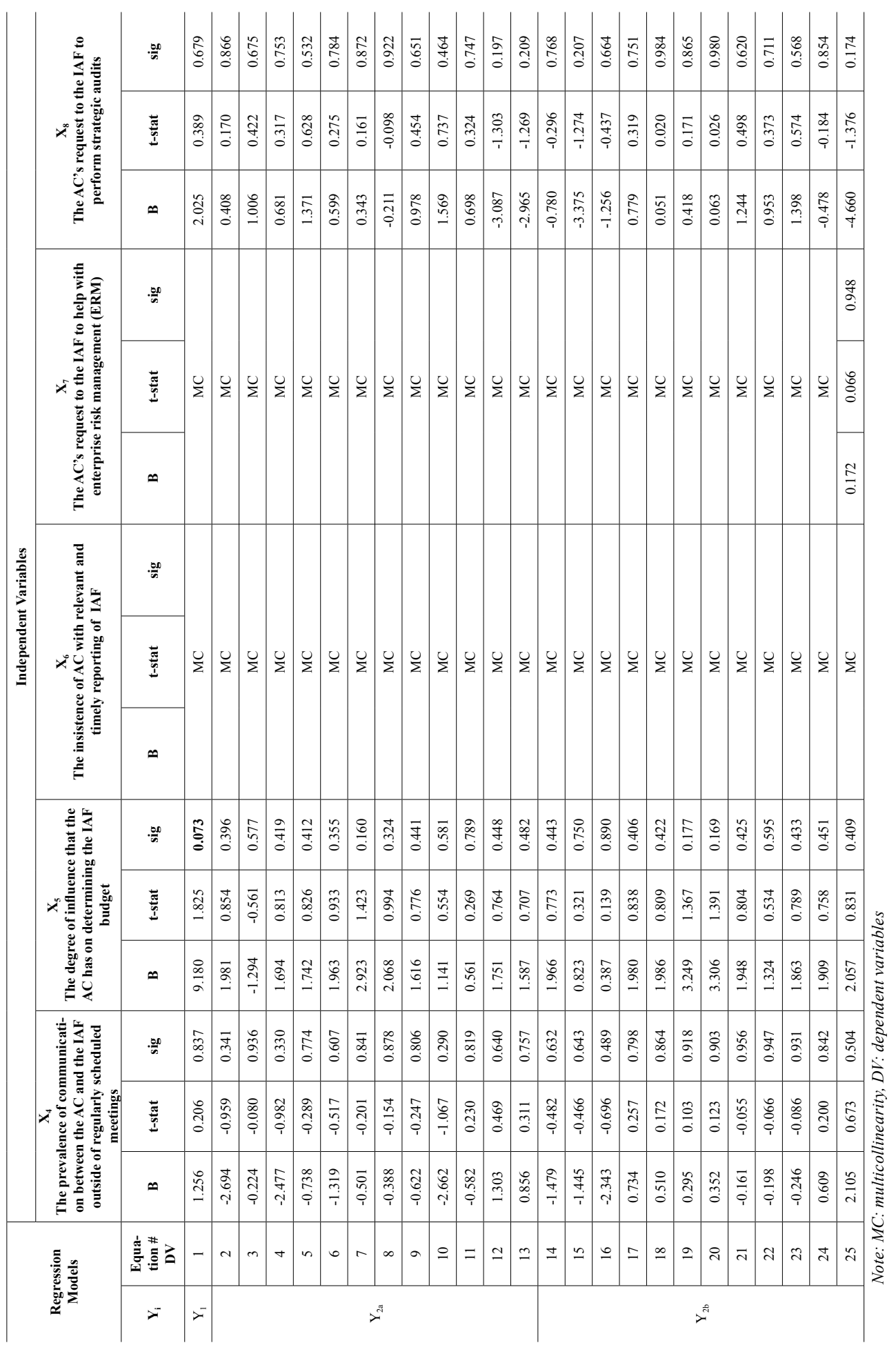




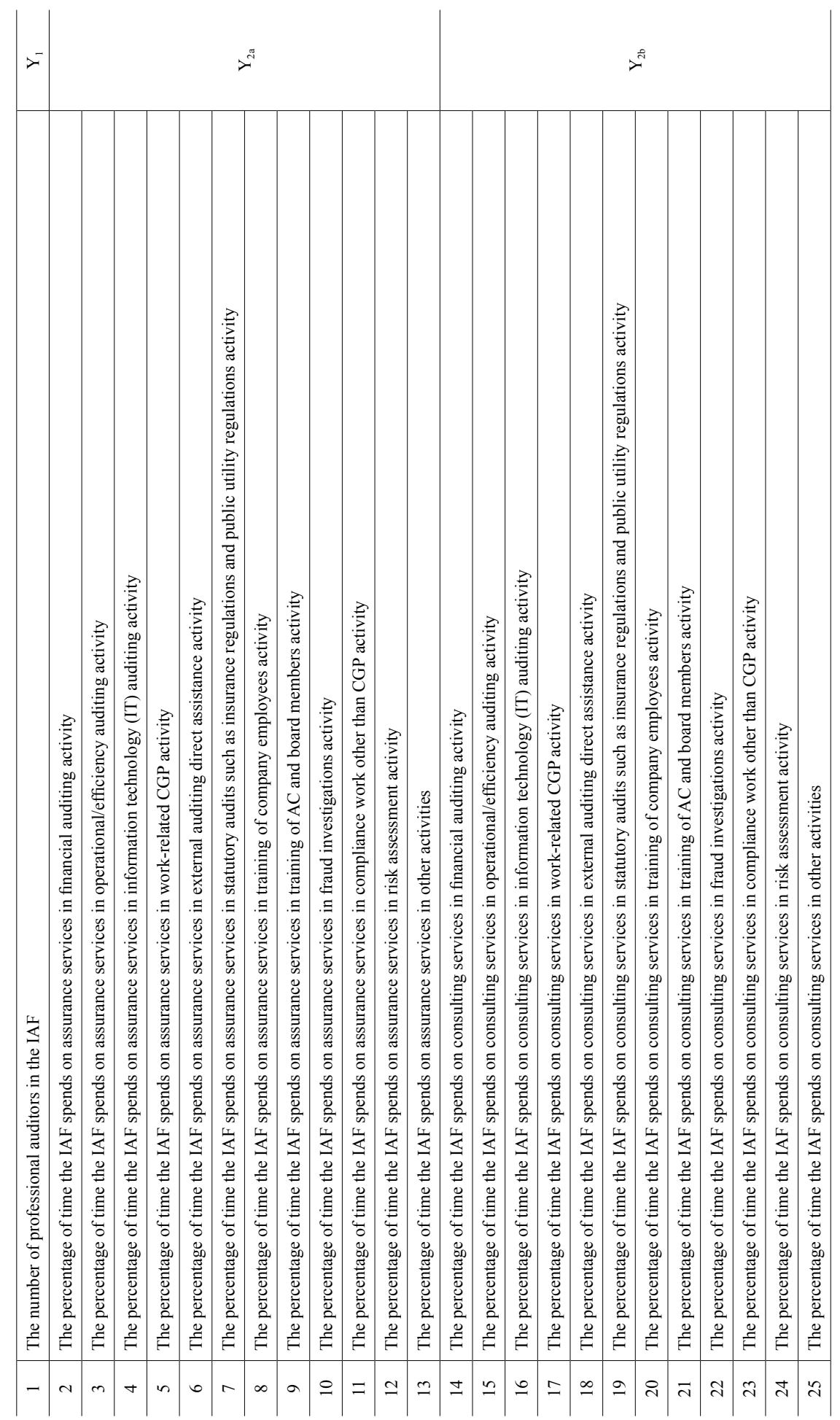

